\title{
EVALUASI PROGRAM UJIAN NASIONAL (UN) PADA SMK NEGERI DI JAKARTA SELATAN
}

\author{
Henry Eryanto \\ Fakultas Ekonomi, Universitas Negeri Jakarta \\ henryeryanto@gmail.com \\ Marsofiyati \\ Fakultas Ekonomi, Universitas Negeri Jakarta \\ mersofiyati@gmail.com \\ Darma Rika Swaramarinda \\ Fakultas Ekonomi, Universitas Negeri Jakarta \\ darmarika@gmail.com
}

\begin{abstract}
This study aims to determine Evaluation Program of the National Examination (UN) in the State Vocational School in South Jakarta. This study includes qualitative research, where research in SMK who has the Office Administration Program in South Jakarta, which contained 10 SMKN. The resources are empirically Principal and Chairman of the Program Office Administration. Collecting data using the method of observation, interviews, documentation and archive footage, while the analysis of data using qualitative data analysis interactive model.

The results showed that: (1) Implementation of UN 2015 went well, although there are still obstacles to the program, but this is normal and can be controlled quickly and well. (2) The 2015 UN Program is a pilot program, where this year the UN goal is to assess the achievement of national competency standards on a particular subject. (3) The results of the UN as a basis for mapping the quality of programs and or education units, consideration of selection into the next level of education and training as well as providing assistance to the education unit in its efforts to improve the quality of education, not as a determinant of graduation of students. (4) each learner formal education and non-formal education pathways equality eligible for the national exam and has the right to repeat the extent not otherwise meet the criteria of achievement of competence of graduates, and every student must attend one national exam at no charge.
\end{abstract}

Keywords: Evaluation Program, National Exam 


\section{PENDAHULUAN}

\section{Latar Belakang}

Dalam rangka peningkatan mutu pendidikan, peran serta dan dukungan semua pihak yang terkait sangat dibutuhkan baik dari pihak sekolah, masyarakat, maupun pemerintah. Oleh karena itu, Peraturan Pemerintah Nomor 19 Tahun 2005 pasal 63 ayat 1 mengamanatkan tiga jenis penilaian yang dilakukan terhadap peserta didik. Salah satunya, penilaian hasil belajar yang harus dilakukan oleh pemerintah. Dalam pasal 66 bentuk penilaian yang dilakukan pemerintah tersebut dilakukan dalam bentuk Ujian Nasional untuk mata pelajaran tertentu.

Banyak hal yang sebenarnya mendiskritkan ujian nasional, tidak hanya dari kalangan masyarakat tetapi juga dari kalangan lembaga pendidikan sendiri. Dalam UU No. 20 Tahun 2003 tentang Sistem Pendidikan Nasional, evaluasi pendidikan adalah kegiatan pengendalian, penjamin, dan penetapan mutu pendidikan terhadap berbagai komponen pendidikan pada setiap jalur, jenjang, dan jenis pendidikan sebagai bentuk pertanggungjawaban

penyelenggaraan pendidikan. Jadi sampai dengan sekarang masih banyak pro dan kontra dalam penyelenggaraan UN.

Berdasarkan latar belakang tersebut, maka peneliti bermaksud melihat bagaimana evaluasi program Ujian Nasional
(UN) pada SMK Negeri di Jakarta Selatan.

\section{Pembatasan Masalah}

Untuk mencapai hasil yang optimal, penelitian ini dibatasi pada masalah bagaimana evaluasi terhadap Program Ujian Nasional (UN) dilihat dari aspekaspek konteks, input, proses dan produk.

\subsection{Perumusan Masalah}
1. Bagaimanakah konteks perencanaan dan penyelenggaraan Program Ujian Nasional?

2. Bagaimanakah input Program Ujian Nasional ditinjau dari jumlah anggaran, pedoman/juklak/juknis, SDM pelaksana, serta sarana dan prasarana?

3. Bagaimanakah proses Program Ujian Nasional, ditinjau dari pelaksanaan program serta hambatan/kendala?

4. Bagaimanakah produk Program Ujian Nasional, ditinjau dari outcome program?

\section{Tujuan Penelitian}

Secara khusus, tujuan penelitian ini adalah untuk:

1. Mengevaluasi Program Ujian Nasional dan mengetahui sejauh mana tingkat keberhasilan dari program tersebut.

2. Mengetahui kendala/hambatan dalam implementasi kebijakan 
mengenai program tersebut.

3. Mengetahui masyarakat implementasi mengenai program tersebut.

diadakannya

respon

terhadap

kebijakan diadakannya

KAJIAN PUSTAKA

\subsection{Deskripsi Kebijakan Publik dan Kebijakan Pendidikan}

Kebijakan yang dibuat oleh pemerintahan suatu Negara merupakan kebijakan publik karena akan berdampak terhadap kehidupan warga Negara di dalam Negara tersebut. Oleh karena itu sebuah kebijakan yang dibuat oleh suatu pemerintahan seharusnya tidak merugikan warga negaranya, artinya bahwa setiap kebijakan yang ditetapkan seharusnya berpihak kepada warga Negara. Tetapi tidak dapat dipungkiri bahwa setiap kebijakan yang dibuat oleh pemerintah merupakan suatu hasil dari respon terhadap sesuatu yang dipengaruhi oleh berbagai hal seperti tekanan dari sekelompok masyarakat yang mempunyai pengaruh di kalangan pemerintah, bisa maupun memang keinginan dari kelompok penguasa dalam suatu pemerintahan itu sendiri.

Kebijakan publik adalah istilah yang sudah tidak asing lagi bagi masyarakat karena istilah ini sudah sering didengar dalam kehidupan sehari-hari. Parsons (2006) dalam bukunya mengatakan bahwa pertumbuhan kebijakan publik sebagai suatu kajian di dunia akademik diperkirakan mulai pada akhir tahun 1960 an.

Berdasarkan pendapat dari Parson ini tampaknya ketertarikan para akademisi untuk mengkaji bidang ini sudah cukup lama apalagi saat ini berbagai kajian dan penelitian kebijakan publik sedang ngetren di perguruan tinggi Indonesia terutama setelah reformasi tahun 1998 dimana tuntutan terhadap good governance pada pemerintah semakin menguat sehingga proses kebijakan publik sejak mulai dirumuskan sampai dengan dievaluasi dilakukan bersama antara pemerintah dengan masyarakat. Sesuai dengan pendapat Gambhir Bhatta dalam Riant Nugroho (2009) "governance is the relationship between government and citizens that enable public policies and programs to be formulated, implemented and evaluated". Pemerintahan adalah hubungan antara pemerintah dengan masyarakat yang memungkinkan kebijakan publik dan program yang akan dirumuskan, dilaksanakan dan di evaluasi.

$$
\text { Kemudian }
$$

Steven A.Peterson (2003) mengatakan bahwa yang dimaksud dengan kebijakan publik adalah: "Government action to address some problem". Maksudnya adalah: Berbagai tindakan pemerintah untuk menyelesaikan berbagai masalah. Selanjutnya 
menurut James Lester dan Robert Steward (2000) mendefinisikan Kebijakan publik adalah : "a process or a series or pattern of governmental activities or decisions that are design to remedy some public problem, either real or imagined", maksudnya adalah "satu proses atau satu seri atau pola kegiatankegiatan atau keputusankeputusan pemerintah yang dirancang untuk memperbaiki beberapa masalah umum, baik yang nyata atau yang tidak nyata.

Selanjutnya menurut Anderson (1978) dalam Islamy (2003) pengertian kebijakan publik adalah: "Public policies are those develoved by governmental bodies and officials". Sedangkan menurut Dye (1972) dalam Wahab (1990), bahwa kebijakan publik adalah "whatever governments choose to do or not to do". Dunn (1994), ia mendefinisikan bahwa kebijakan publik adalah "a complex pattern of interdependent collective choice, including decisions not act, made by governmental bodies and official". Pengertian Dunn dapat dipahami bahwa kebijakan publik mengedepankan berbagai hal dengan berdasarkan pola-pola yang bersifat kolektif, komplek, dan saling ketergantungan, dilakukan tidak hanya oleh pejabat pemerintah, melainkan juga oleh lembaga pemerintah secara keseluruhan. Demikian juga Easten (Easton, 1953) yang menyatakan bahwa kebijakan publik sebagai: the authoritative allocation of Values for the whole society".Yang artinya kebijakan publik adalah pengalokasian nilai-nilai secara sah/paksa kepada masyarakat. William Jenkins dalam bukunya Policy Analiysis: $A$ Political and Organization Perspective yang dikutip Howlett and Ramesh (1995) bahwa kebijakan publik sebagai "a set of interrelated decision taken by a political actor or group of actors concerning the selection of goals and the means of achieving them within a specified situation where those decision should, in principal, be within the power of those actors to acieve". (Howlett, 1995)

Jones (1984) yang mengutip pendapat Eula dan Prewitt, berpendapat hampir senada dengan Gerston dengan mengemukakan bahwa kebijakan publik sebagai keputusan tetap yang dicirikan oleh konsistensi dan pengulangan tingkah laku dari mereka yang membuat dan dari mereka yang mematuhi keputusan tersebut.

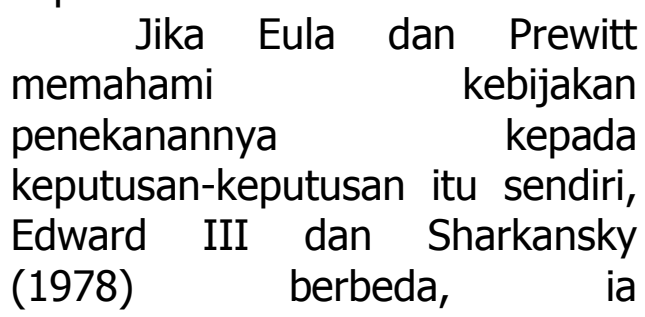
mengemukakan bahwa kebijakan adalah apa yang dilakukan dan tidak dilakukan oleh pemerintah memiliki tujuan dan maksud yang jelas dan merupakan programprogram pemerintah yang akan 
dilaksanakan. Nakamura dan Smallowood (1980), hampir senada dengan Eula dan Prewitt, menurutnya bahwa kebijakan public adalah "serangkaian instruksi kepada para pembuat kebijakan yang menjelaskan tujuan dan cara-cara untuk mencapai tujuan tersebut".

Secara umum, dari beberapa definisi yang dikemukakan di atas, dapat disimpulkan bahwa pandangan mengenai kebijakan publik terbagi ke dalam Dua kelompok. Pertama, kelompok yang memandang kebijakan publik sebagai suatu tindakan atau apaapa yang sebenarnya dilakukan; kedua, kelompok yang menekankan bahwa kebijakan publik merupakan suatu rangkaian keputusan.

Dengan demikian, dari beberapa pendapat pakar kebijakan publik tersebut di atas dapat disimpulkan bahwa kebijakan publik merupakan suatu rangkaian keputusan yang dibuat oleh individu, lembaga atau pemerintah mengenai urusan publik yang mengarahkan tindakan yang mempunyai tujuan, sasaran, dan maksud tertentu sebagai upaya mengatasi permasalahan publik agar menjadi lebih baik dan sesuai dengan yang diharapkan.

Dalam konteks penelitian ini yang dimaksud dengan kebijakan publik adalah rangkaian perundang-undangan atau keputusan-keputusan mengenai pendidikan nasional, khususnya tentang penyelenggaraan Program Wajib Belajar Pendidikan Dasar.

Sesuai dengan pendapat Gambhir Bhatta dalam Riant Nugroho (2009) "governance is the relationship between government and citizens that enable public policies and programs to be formulated, implemented and evaluated". Atau dengan pengertian lain, pemerintahan adalah hubungan antara pemerintah dengan masyarakat yang memungkinkan kebijakan publik dan program yang akan dirumuskan, dilaksanakan dan di evaluasi.

\subsection{Program Ujian Nasional} (UN)

Ujian Nasional (UN) adalah kegiatan penilaian hasil belajar peserta didik yang telah menyelesaikan jenjang pendidikan pada jalur sekolah/madrasah yang diselenggarakan secara nasional. Jadi, berdasarkan pengertian tersebut, dapat penulis simpulkan bahwa yang disebut UN itu merupakan suatu kegiatan yang dilakukan oleh sekolah/madrasah terhadap kegiatan siswa berupa penilaian hasil belajar yang diikuti oleh para siswa yang telah menyelesaikan jenjang pendidikan atau siswa yang telah berada pada kelas akhir sebagai salah satu syarat mengetahui mutu atau kemampuan siswa dalam menguasai ilmu pengetahuan yang telah diajarkan dan siswa yang telah melakukan kegiatan tersebut 
miliki hak untuk melanjutkan pendidikan ke jenjang berikutnya jikalau hasil yang diperoleh adalah memutuskan demikian.

Adapun UN menurut

Peraturan Mentri Pendidikan

Nasional RI Nomor 20 Tahun 2005 Pasal 4, dijadikan pertimbangan untuk:

a. penentuan kelulusan peserta didik dari suatu satuan pendidikan,

b. seleksi masuk jenjang pendidikan selanjutnya,

c. pemetaan mutu satuan dan/ atau program pendidikan,

d. akreditasi satuan pendidikan, dan

e. pembinaan dan pemberian bantuan pada satuan pendidikan dalam upaya peningkatan mutu pendidikan.

Dasar Hukum Ujian Nasional (UN)

a. Undang-undang Nomor 22 Tahun 1999 tentang Pemerintah Daerah.

b. Undang-undang Nomor 20 Tahun 2003 Tentang Sistem Pendidikaan Nasional.

c. Peraturan Pemerintah Nomor 28 Tahun 1990 Tentang pendidikan Dasar.

d. Peraturan Pemerintah Nomor 29 Tahun 1990 Tentang Pendidikan Menengah.

e. Keputusan Menteri Pendidikan dan Kebudayaan Republik Indonesia Nomor 144 Tahun 2014 Tentang Kriteria Kelulusan Peserta Didik dari Satuan Pendidikan dan Penyelenggaraan Ujian
Sekolah/Madrasah/Pendidikan/ Kesetaraan dan Ujian Nasional.

f. Peraturan Menteri Pendidikan dan Kebudayaan Republik Indonesia Nomor 5 Tahun 2015 Tentang Kriteria Kelululusan Peserta Didik, Penyelenggaraan Ujian Nasional, dan Penyelenggaraan Ujian Sekolah/Madrasah/Pendidikan Kesetaraan Pada SMP/MTs atau yang Sederajat dan SMA/MA/SMK atau yang Sederajat.

\section{Tujuan Ujian Nasional (UN)}

Menurut keputusan Menteri Pendidikan Nasional No. 153/U/2003 tentang Ujian Nasional, disebutkan bahwa tujuan Ujian Nasional adalah untuk mengukur pencapaian hasil belajar peserta didik melalui pemberian tes kepada siswa, selanjutnya dipertegas dalamPeraturan Menteri Pendidikan dan Kebudayaan Republik Indonesia Nomor 5 Tahun 2015, Ujian Nasional Ujian Nasional yang selanjutnya disebut UN adalah kegiatan pengukuran dan penilaian pencapaian kompetensi lulusan secara nasional pada mata pelajaran tertentu. Selain itu Ujian Nasional bertujuan untuk mengukur mutu pendidikan dan mempertanggungjawabkan penyelenggaraan pendidikan di tingkat Nasional, provinsi, kabupaten, sampai di tingkat sekolah. 
Dengan demikian, berdasarkan isi pasal di atas maka dapat diambil suatu kesimpulan bahwa tujuan dari dilaksanakannya Ujian Nasional (UN) tersebut adalah sebagai pengatur untuk mencapai hasil belajar para siswa di sekolah, disamping itu juga sebagai pengukur mutu atau kualitas pendidikan yang selama ini diselenggarakan oleh sekolah/ madrasah masing-masing sehingga dapat diketahui berhasil tidaknya tujuan masing-masing lembaga tersebut serta untuk mempertanggungjawabkan pendidikan yang telah dilakukan kepada masyarakat sebagai penerima kelulusan.

Hasil Ujian Nasional digunakan sebagai dasar untuk:

a. pemetaan mutu program dan/atau satuan pendidikan;

b. pertimbangan seleksi masuk jenjang pendidikan berikutnya;

c. pembinaan dan pemberian bantuan kepada satuan pendidikan dalam upayanya untuk meningkatkan mutu pendidikan.

\section{Fungsi Ujian Nasional (UN)}

Fungsi UN pun telah termaktub dalam Keputusan Mendiknas. Nomor 153, yang terdapat dalam pasal 3, yaitu berfungsi sebagai:

a. Alat pengendali mutu pendidikan secara nasional;

b. Pendorong peningkatan mutu pendidikan

c. Bahan dalam menentukan kelulusan peserta didik.

Ad. a) Alat pengendali mutu pendidikan secara nasional maksudnya adalah bahwa UN merupakan alat untuk dapat mengetahui mutu pendidikan secara nasional dan dapat pula memperbaiki kekurangan-kekurangan yang terdapat dalam pelaksanaan UN pada tahun berikutnya.

Ad. b) Pendorong peningkatan mutu pendidikan maksudnya adalah dengan adanya UN diharapkan tingkat kompetisi untuk berprestasi semakin meningkat di antara sekolah/ madrasah maupun antara peserta didik, karena mengetahui tolak ukur dari kualitas lulusan peserta didik yang lulus pada tahun tersebut, hingga memotivasi untuk dapat menjadi lebih baik lagi.

Ad. c) Bahan dalam menentukan kelulusan peserta didik maksudnya UN diadakan tidak lain adalah untuk mengukur kemampuan siswa serta memutuskan untuk lulus tidaknya seorang 
peserta didik untuk dapat melanjutkan ke jenjang berikutnya.

\subsection{Evaluasi Program}

\subsubsection{Pengertian}

Menurut Wirawan (2011), evaluasi di bidang pendidikan ada 2 macam yaitu: evaluasi hasil belajar dan evaluasi program pendidikan. Lebih lanjut Wirawan mengatakan bahwa "evaluasi belajar bertujuan untuk mengukur apakah pembelajaran berbagai bidang ilmu mencapai tujuan yang telah ditentukan oleh kurikulum pembelajaran ilmu tersebut. Evaluasi ini dilakukan melalui pekerjaan rumah, ulangan umum, dan ujian nasional. Evaluasi program pendidikan untuk mengevaluasi berbagai aspek pendidikan misalnya, kurikulum, proses dan metode pembelajaran mata pelajaran, layanan pendidikan, tenagapendidikan dan sebagainya".

Menurut Suharsimi Arikunto (Arikunto, 2012), "kata yang selalu berkaitan dengan kata evaluasi tersebut adalah: evaluasi (evaluation), pengukuran (measurement), dan penilaian (assessment)." Ditambahkan pula oleh Arikunto bahwa, "Evaluasi adalah kegiatan untuk mengumpulkan informasi tentang bekerjanya sesuatu, yang selanjutnya informasi tersebut digunakan untuk menentukan alternatif yang tepat dalam mengambil keputusan.

Menurut Stufflebeam, dkk (1971) dalam Suharsimi (2007) mendefinisikan evaluasi sebagai "the process of delineating, obtaining, and providing useful information for judging decision alternatives," Artinya evaluasi merupakan proses menggambarkan, memperoleh, dan menyajikan informasi yang berguna untuk merumuskan suatu alternatif keputusan.

Menurut Wirawan (2011), "Pada awal 1930 Ralph Winfred Tyler yang kemudian dikenal sebagai bapak evaluasi ia mengemukakan definisi dan teorinya mengenai evaluasi yang memfokuskan pada menilai apakah tujuan suatu program tercapai atau tidak yang kemudian dikenal sebagai Goal based evaluation model."

Selanjutnya

menurut

Wawan (Wawan, 2011) ada beberapa istilah yang berkaitan dengan pengertian: a). Evaluasi program dan evaluasi hasil belajar. b). Asesmen (assessment) merupakan kegiatan menentukan kedudukan suatu objek pada sejumlah variabel yang menjadi fokus. c). Pengukuran (measurement), adalah kegiatan penempatan nilai numerikal atau angka terhadap suatu objek dengan menggunakan instrumen. Sedangkan program menurut Arikunto (Arikunto, 2012) yaitu "program adalah suatu rencana yang melibatkan berbagai unit yang berisi kebijakan dan rangkaian kegiatan yang harus dilakukan dalam kurun waktu tertentu". 
Dilanjutkan oleh

Suharsimi Arikunto (Arikunto, 2012) bahwa, "Evaluasi program adalah suatu unit atau kesatuan kegiatan yang bertujuan mengumpulkan informasi tentang realisasi atau implementasi dari suatu kebijakan, berlangsung dalam proses yang berkesinambungan, dan terjadi dalam suatu organisasi yang melibatkan sekelompok orang guna pengambilan keputusan".

Jadi dapat disimpulkan bahwa evaluasi program merupakan rangkaian kegiatan yang dilakukan dengan sengaja dan secara cermat untuk mengetahui tingkat keterlaksanaan atau keberhasilan suatu program dengan cara mengetahui efektivitas masingmasing komponennya, baik terhadap program yang sedang berjalan maupun program yang telah berlalu.

\subsubsection{Dimensi Evaluasi Program}

Setelah kita menentukan obyek evaluasi selanjutnya harus menentukan aspek-aspek dari obyek yang akan evaluasi.

\subsubsection{Tujuan}

Adapun tujuan dari evaluasi program menurut Suharsimi Arikunto (Arikunto S. d., 2007) adalah "untuk mengetahui pencapaian tujuan program yang telah dilaksanakan. Selanjutnya, hasil evaluasi program digunakan sebagai dasar untuk melaksanakan kegiatan tindak lanjut atau untuk melakukan pengambilan keputusan berikutnya".

Evaluasi sama artinya dengan kegiatan supervisi. Kegiatan evaluasi atau supervisi dimaksudkan untuk mengambil keputusan atau melakukan tindak lanjut dari program yang telah dilaksanakan. Manfaat dari evaluasi program dapat berupa penghentian program, merevisi program, melanjutkan program, dan menyebarluaskan program. Menurut Jones (1984), "Implementation of the program should always be evaluated to see how far the program has managed to achieve program objectives previously set". Artinya Implementasi program harus senantiasa dievaluasi untuk melihat sejauh mana program tersebut telah berhasil mencapai tujuan program yang telah ditetapkan sebelumnya. Jadi tanpa adanya evaluasi, program-program yang berjalan tidak akan dapat dilihat efektifitasnya. Dengan demikian, kebijakan-kebijakan baru sehubungan dengan program itu tidak akan didukung oleh data. Karenanya, evaluasi program bertujuan untuk menyediakan data dan informasi serta rekomendasi bagi pengambil kebijakan (decision maker) untuk memutuskan apakah akan melanjutkan, memperbaiki atau menghentikan sebuah program". 


\subsection{Evaluasi Program Ujian Nasional (UN)}

Ujian Nasional (UN) merupakan suatu kegiatan yang dilakukan oleh sekolah/madrasah terhadap kegiatan siswa berupa penilaian hasil belajar yang diikuti oleh para siswa yang telah menyelesaikan jenjang pendidikan atau siswa yang telah berada pada kelas akhir sebagai salah satu syarat mengetahui mutu atau kemampuan siswa dalam menguasai ilmu pengetahuan yang telah diajarkan dan siswa yang telah melakukan kegiatan tersebut memiliki hak untuk melanjutkan pendidikan ke jenjang berikutnya jikalau hasil yang diperoleh adalah memutuskan demikian.

Keberhasilan program UN dapat dilihat dari beberapa indikator capaian yaitu melihat pada kesesesuaian dengan konteks yang ada, melihat input dan proses yang berjalan serta output yang dihasilkan. Di dalam penerapan kebijakan program tersebut, terdapat kendalakendala yang menyebabkan terhambatnya pelaksanaan dari Program UN ini.

\section{METODE PENELITIAN}

\subsection{Metode Penelitian}

Penelitian ini merupakan studi kualitatif yang bertujuan untuk mengetahui hasil dari implementasi kebijakan Program Ujian Nasional (UN), kendala/hambatan dalam implementasi kebijakan tersebut dan mengetahui respon masyarakat

terhadap implementasi kebijakan.

\subsection{Model Penelitian Evaluasi} Peneliti menggunakan evaluasi model CIPP dengan menggunakan pendekatan deskriptif kualitatif.

\subsection{Sumber Data}

1. Data Primer yang diambil langsung dari responden menggunakan kuesioner dan wawancara mengenai konteks, input, proses dan produk dari program Ujian Nasional (UN).

2. Data Sekunder yang diperoleh dari SMK Negeri di Jakarta Selatan.

\subsection{Teknik Pengumpulan Data}

Teknik pengumpulan data
dalam penelitian adalah
Observasi atau pengamatan dan.
Wawancara
Pengumpulan
$\begin{array}{lr}\text { dilakukan melalui wawancara } \\ \text { mendalam }\end{array}$ interview)kepada key informan SMK Negeri di Jakarta Selatan yang memiliki Program Studi Administrasi Perkantoran, sebanyak 10 Sekolah, yaitu SMKN 6, SMKN 8, SMKN 15, SMKN 18, SMKN 20, SMKN 25, SMKN 41, SMKN 43, SMKN 47, dan SMKN 62. Adapun Key Informamya adalah Kepala SMK dan Ketua Program Studi Administrasi Perkantoran.

\subsection{Analisis Data}


Dalam pelaksanaan analisis data kualitatif bertujuan pada penggalian makna, penggambaran, penjelasan dan penempatan data pada konteksnya masing-masing.

Available at:

http://journal.unj.ac.id/unj/index.php/econosains/article/view/688 
Tabel 3.1 Perencanaan

Evaluasi

\begin{tabular}{|c|c|c|c|}
\hline Aspek/Indikator & Sumber Data & Teknik & $\begin{array}{l}\text { Tahap } \\
\text { Evalua } \\
\text { si }\end{array}$ \\
\hline 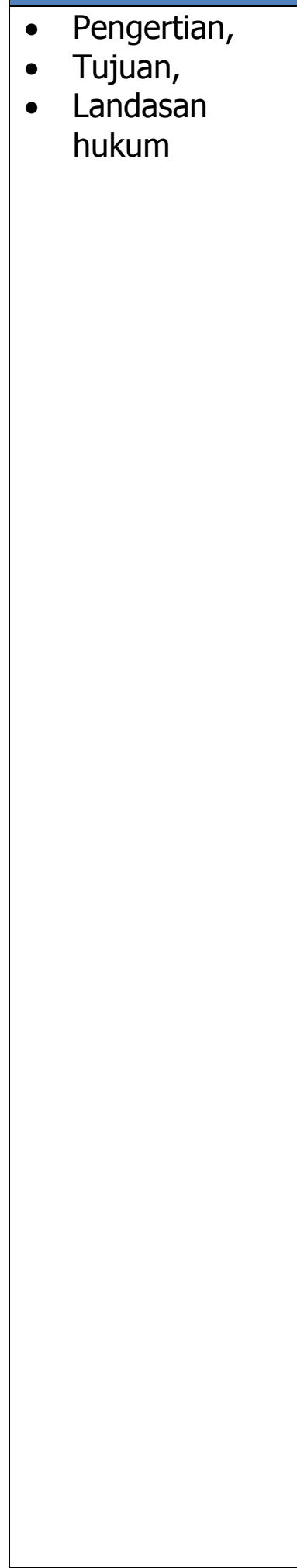 & 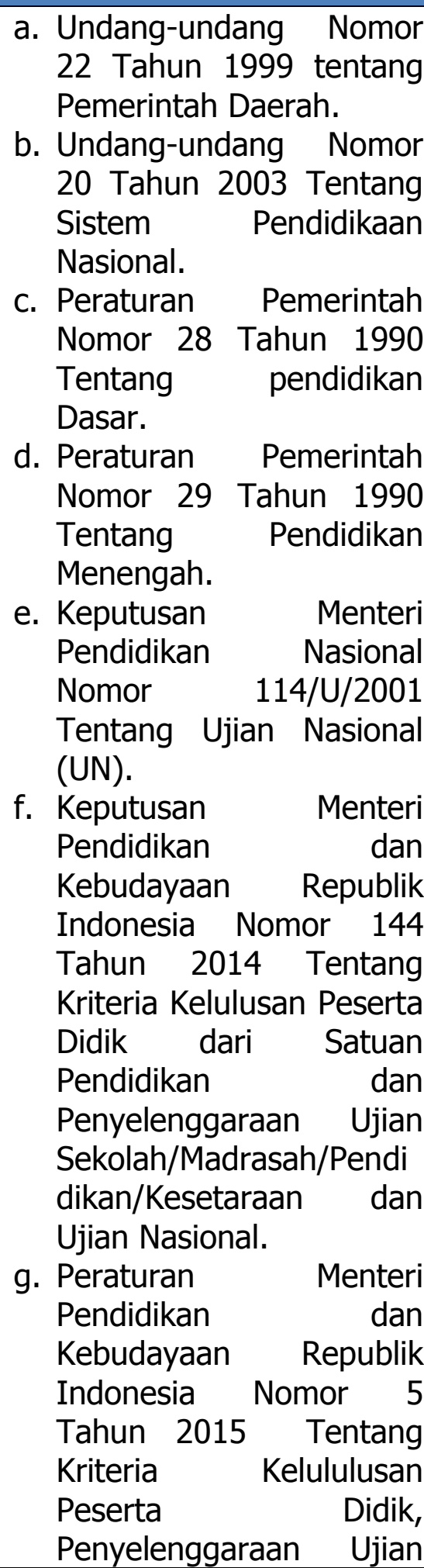 & $\begin{array}{ll}\text { - } & \text { Analisis } \\
& \text { Dokume } \\
\mathrm{n} \\
\text { - } \\
\text { Wawanc } \\
\text { ara }\end{array}$ & $\begin{array}{l}\text { Kontek } \\
\text { s }\end{array}$ \\
\hline
\end{tabular}




\begin{tabular}{|c|c|c|c|}
\hline & 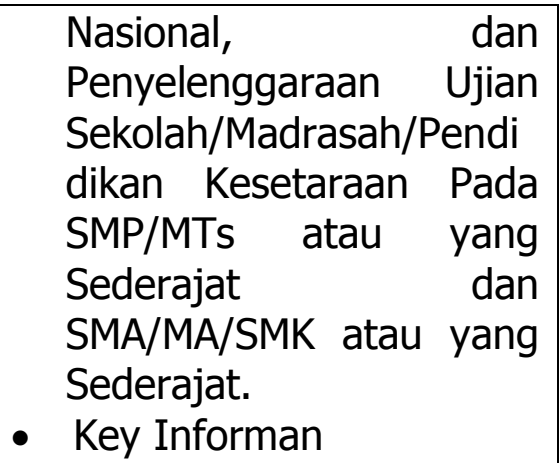 & & \\
\hline $\begin{array}{l}\text { - Peserta, } \\
\text { - } \text { Persyaratan } \\
\text { peserta, } \\
\text { - Sarana } \\
\text { prasarana, } \\
\text { - Biaya/Dana } \\
\end{array}$ & - Key Informan & $\begin{array}{l}\text { - Analisis } \\
\text { Dokume } \\
\mathrm{n} \\
\text { - Wawanc } \\
\text { ara }\end{array}$ & Input \\
\hline $\begin{array}{l}\text { - } \text { Perencanaan } \\
\text { - Pelaksanaan } \\
\text { - Pengawasan } \\
\text { - } \quad \text { Evaluasi } \\
\text { Program UN }\end{array}$ & $\begin{array}{l}\text { - Panduan Program UN } \\
\text { - Key Informan }\end{array}$ & $\begin{array}{l}\text { - Analisis } \\
\text { Dokume } \\
\mathrm{n} \\
\text { - Wawanc } \\
\text { ara }\end{array}$ & Proses \\
\hline $\begin{array}{l}\text { Kompetensi } \\
\text { lulusan } \\
\text { program UN }\end{array}$ & $\begin{array}{l}\text { - Panduan Program UN } \\
\text { Dikti } \\
\text { - Key Informan }\end{array}$ & $\begin{array}{ll}\text { - } & \text { Analisis } \\
\text { Dokume } \\
\mathrm{n} \\
\text { - } \text { Wawanc } \\
\text { ara }\end{array}$ & Produk \\
\hline
\end{tabular}

\subsection{Hasil Penelitian}

Evaluasi Context (Konteks) Program Ujian Nasional (UN)

Beberapa hal yang dapat dievaluasi dari konteks Program Ujian Nasional (UN) ini, yaitu:

1. Terdapat beberapa dasar hukum yang mendasari UN 2015, Di mana dasar hukum tersebut merupakan landasan utama penyelenggaraan Ujian Nasional (UN) 2015, yang mulai tahun
Terdapat Dasar Hukum yang Mendasari kegiatan UN 2015

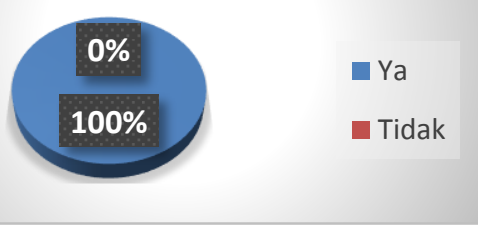

2.Dasar hukum yang mendasari UN 2015, yaitu Undang-undang Nomor 20 Tahun 2003 Tentang Sistem Pendidikaan Nasional, Peraturan Pemerintah Nomor 29 
Tahun 1990 Tentang Pendidikan Menengah, Keputusan Menteri Pendidikan Nasional Nomor 114/U/2001 Tentang Ujian Nasional (UN), Keputusan Menteri Pendidikan dan Kebudayaan Republik Indonesia Nomor 144 Tahun 2014 Tentang Kriteria Kelulusan Peserta Didik dari Satuan Pendidikan dan Penyelenggaraan Ujian Sekolah/Madrasah/Pendidikan/K esetaraan dan Ujian Nasional, Peraturan Menteri Pendidikan dan Kebudayaan Republik Indonesia Nomor 5 Tahun 2015 Tentang Kriteria Kelululusan Peserta Didik, Penyelenggaraan Ujian Nasional, dan Penyelenggaraan Ujian

Sekolah/Madrasah/Pendidikan

Kesetaraan Pada SMP/MTs atau yang Sederajat dan SMA/MA/SMK atau yang Sederajat. Di mana dasar hukum tersebut merupakan landasan utama penyelenggaraan Ujian Nasional (UN) 2015, yang mulai tahun 2015 ini bukan menjadi penentu kelulusan siswa, tetapi masih ada indikator lain yang menentukan kelulusan tersebut, yaitu ujian sekolah, hal ini tercantum dalam hal ini tercantum di dalam Permendikbud No 44/2014 tentang Ujian Nasional. Peraturan Menteri Pendidikan dan Kebudayaan Republik Indonesia Nomor 5 Tahun 2015.Peserta didik dinyatakan lulus dari satuan pendidikan setelah menyelesaikan seluruh program pembelajaran, memperoleh nilai sikap/perilaku minimal baik, dan lulus Ujian S/M/PK.

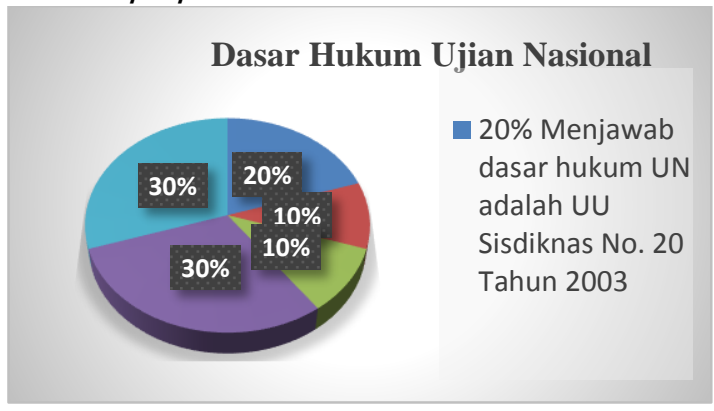

\section{Indikator Keberhasilan Tahap Konteks Program NASIONAL (UN) \\ UJIAN}

Jika melihat dari beberapa evaluasi pada konteks program Ujian Nasional (UN) di atas, maka dapat disimpulkan bahwa implementasi dari konteks program tersebut sudah baik, karena Program Ujian Nasional memiliki dasar hukum yang sudah diperbarui terutama perubahan tujuan Ujian Nasional, yang sebelumnya adalah penentu kelulusan, tapi mulai tahun 2015 tidak dijadikan penentu kelulusan.

\section{Evaluasi Input Program Ujian Nasional (UN)}

Beberapa hal yang dapat dievaluasi dari input Program Ujian Nasional (UN) ini, yaitu dalam hal Anggaran ketersediaan anggaran program Ujian Nasional (UN) semua responden menjawab telah tersedia anggaran untuk program ini. Hal ini dapat terlihat dari prosentasi hasil wawancara berikut ini. 
Tersedia anggaran untuk kegiatan UN

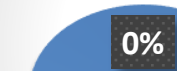

$0 \%$

$100 \%$

1. Ketersediaan anggaran tersebut, menurut hasil wawancara bahwa sebagian besar menjawab anggaran untuk program Ujian Nasional (UN) sudah sesuai dengan kebutuhan dalam pelaksanaan Ujian Nasional (UN). Hal tersebut dapat dilihat dari diagram Pie berikut ini:

Anggaran Untuk Kegiatan UN

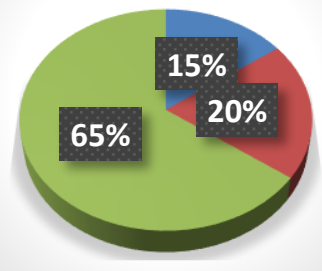

2. Ketersediaan POS (Prosedur Operasional Standar) UN telah dikemukakan oleh seluruh responden.

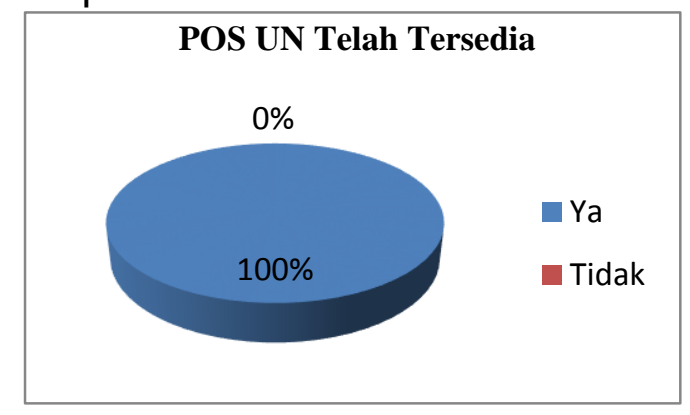

3. POS Ujian Nasional (UN) ini merupakan panduan dalam melaksanakan Ujian Nasional (UN)Nyang berisi tentang Dasar Hukum, Tujuan dan Manfaat Ujian Nasional, Kriteria Kelulusan, Perbandingan UN 2014 dengan UN 2015, Persyaratan Peserta UN, Penyelenggara dan Pelaksana UN, Peran Perguruan Tinggi, Pelaksanaan UN terdiri dari kisikisi UN, jadwal UN, ujian komptensi SMK/MAK, penggandaan dan pendistribusian bahan UN, biaya pelaksanaan UN, pelanggaran dan sanksi, penjaminan kredibilitas UN, dan Pusat Informasi UN.

\section{$100 \%$ Pelaksanaan UN telah sesuai POS}

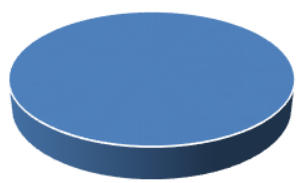

4. Pada pelaksanaan Ujian Nasional 2015 ini, $100 \%$ responden menjawab bahwa SDM Pelaksana sudah tersedia dan sesuai dengan kebutuhan, di mana panitia UN dibentuk dari tingkat pusat sebagai penyelenggara dan pelaksan termasuk di dalamnya UN Luar Negeri, pelaksana tingkat provinsi, pelaksana tingka kabupaten/Kota, pelaksana Tingkat Satuan Pendidikan.

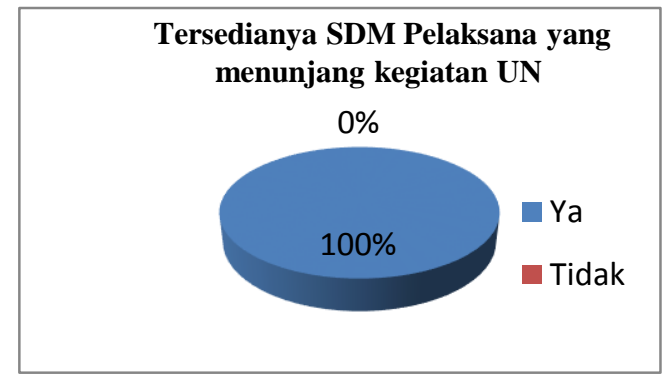


5. Dalam hal Sumber Daya Manusia Pelaksana Ujian Nasional (UN), para responden menjawab $90 \%$ SDM sudah lancar dan sudah disiapkan dengan baik, karena UN merupakan hajat tahunan dan rutin dilaksanakan oleh sekolah, $5 \%$ menyatakan bahwa tenaga guru merupakan SDM yang paling berpengaruh dalam tercapainya pelaksanaan UN, dan $5 \%$ mengatakan bahwa pengawas silang dan panitia sekolah masih sangat diperlukan pada pelaksanaan UN.

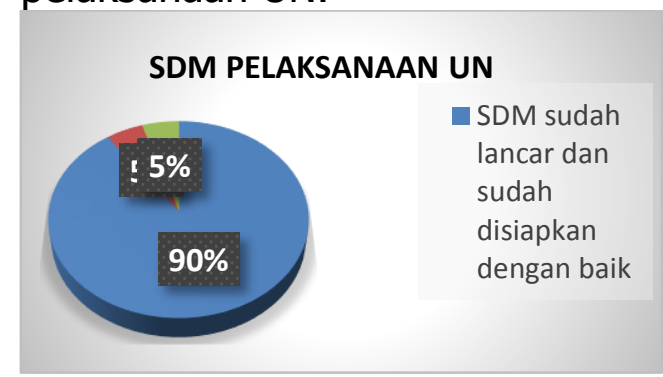

6. Dalam hal persyaratan peserta Ujian Nasional (UN), berdasarkan hasil wawancara hasil yang didapat adalah $100 \%$ responden menilai bahwa peserta yang mengikuti Ujian Nasional (UN) sudah memenuhi persyaratan.

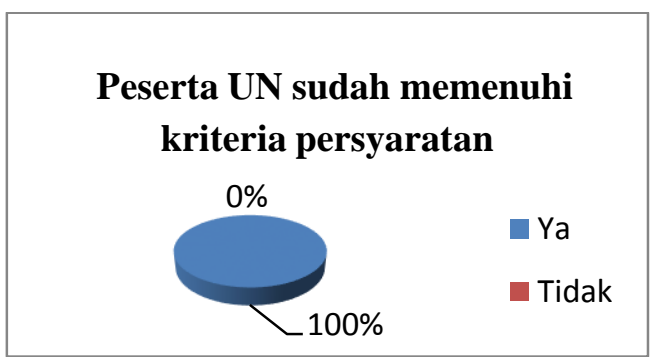

7. Dalam hal persyaratan peserta Ujian Nasional (UN), responden menilai bahwa peserta yang mengikuti UJIAN NASIONAL (UN) sudah memenuhi persyaratan yaitu siswa SMK Kelas XII, yang telah menyelesaikan program pembelajaran dari kelas $X$ sampai dengan kelas XII dan bagi yang menerapkan sistem kredit semester (SKS) telah menyelesaikan seluruh mata pelajaran yang dipersyaratkan sesuai dengan Permendikbud No. 5 Tahun 2015

Kriteria Persyaratan Peserta UN berdasarkan Permendikbud No. 5 Tahun 2015

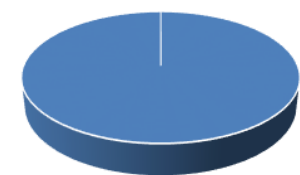

- $100 \%$ sudah memenuhi kriteria berdasarkan Peraturan Menteri Pendidikan dan Kebudyaan Republik Indonesia Nomor 5 Tahun 2015 untuk mengikuti UN 2015

8. Dari segi sarana seluruh responden menjawab, sarana UN telah tersedia dan menunjang kegiatan UN.

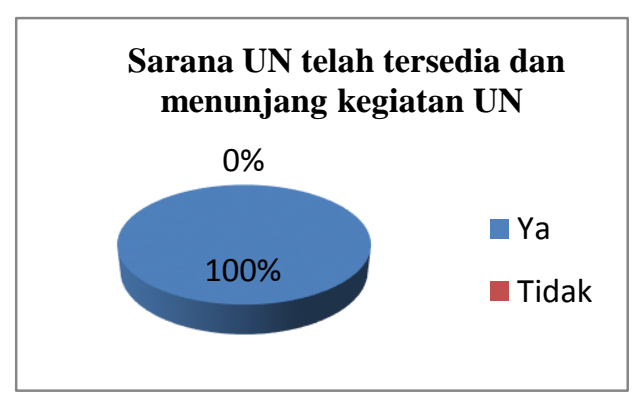

9. Berdasarkan kriteria ketersediaan sarana penunjang kegiatan UN, meskipun pada pernyataan sebelumnya $100 \%$ menjawab 
sudah tersedia, namun sarana tersebut belum sepenuhnya menunjang kegiatan UN. Hal tersebut telihat dari hanya $70 \%$ responden yang menjawab sarana sudah memadai dan telah tersedia dalam menunjang UN, $20 \%$ responden menjawab sarana cukup memadai, dan $10 \%$ sarana masih perlu dilengkapi untuk menunjang keberlangsungan UN.Sarana yang dimaksud adalah sarana UN CBT di mana belum semua sekolah dapat melaksanakan UN CBT.

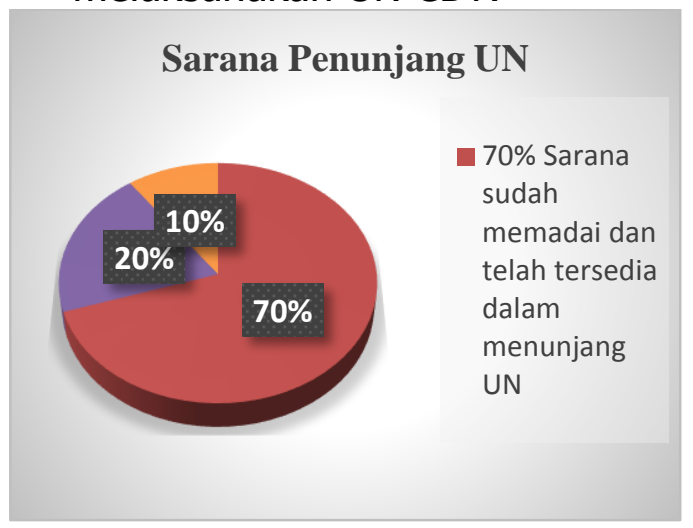

10.Dari segi prasrana UN, seluruh responden menjawab bahwa prasarana UN sudah tersedia.

Prasarana UN telah tersedia dan menunjang kegiatan UN

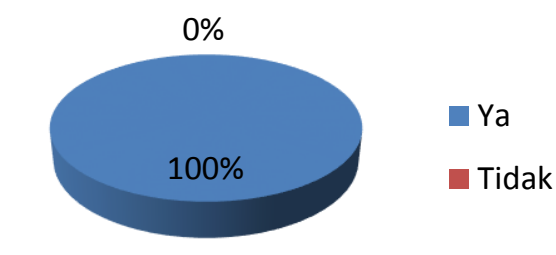

11.Dari segi Prasarana UN, sama halnya dengan sarana secara umum telah tersedia dan menunjang kegiatan UN, namun untuk UN CBT perlu diperhatikan rasio jumlah alat dan peserta UN. Bagi UN PBT perlu diperhatikan jalur distribusi Bahan soal UN. Hal tersebut merupakan bahan masukan dari para kepala sekolah dan ketua Program Studi agar pelaksanaan UN dapat berjalan dengan lancar dan tertib. Walaupun pada tahun 2015 ini, SMKN di Jakarta tidak memiliki permasalahan yang berarti dalam hal pelaksanaan Ujian, namun para responden mengingatkan bahwa sarana dan prasarana dapat menjadi masalah serius jika UN dilaksanakan di daerah-daerah yang jauh dari perkotaan.

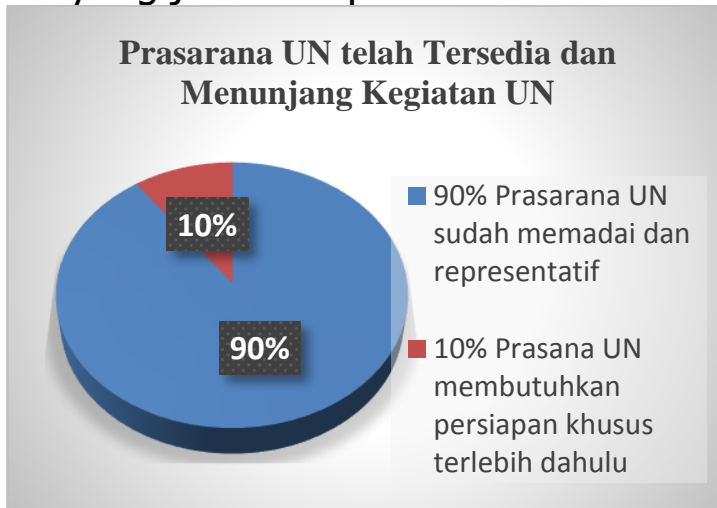

\section{Indikator Keberhasilan Tahap Input Program Ujian Nasional (UN)}

Jika melihat dari beberapa evaluasi pada input program Ujian Nasional (UN) di atas, maka dapat disimpulkan bahwa dari hal ketersediaan anggaran, POS UN, SDM Pelaksana, persyaratan peserta, dan sarana prasarana, yang ada sudah baik, tetapi masih ada beberapa hal yang perlu diperhatikan, yaitu a. masih perlu peningkatan pada sarana dan prasarana UN PBT maupun UN CBT yang memadai sesuai rasio antara peralatan dengan peserta UN, misalnya gedung, kelas, ruang pengawas, ruang panitia, komputer, jaringan internet dan distribusi soal 
yang tepat waktu dan sesuai. b. Perlu tersedianya pengawas silang pada UN CBT, karena obyektivitas pelaksanaan UN tetap harus dipertahankan.

\section{Evaluasi Proses Program Ujian Nasional (UN)}

Beberapa hal yang dapat dievaluasi dari proses Program Ujian Nasional (UN) ini, adalah:

1. Dari segi penyelenggaraan program Ujian Nasional (UN), berdasarkan hasil wawancara dan kuesioner yang didapat maka semua menilai bahwa penyelenggaraan Ujian Nasional (UN) sudah berjalan dengan baik selama ini, karena semua kegiatan sudah berjalan dengan sesuai aturan dan pedoman, sesuai jadwal dan sesuai dengan rencana.

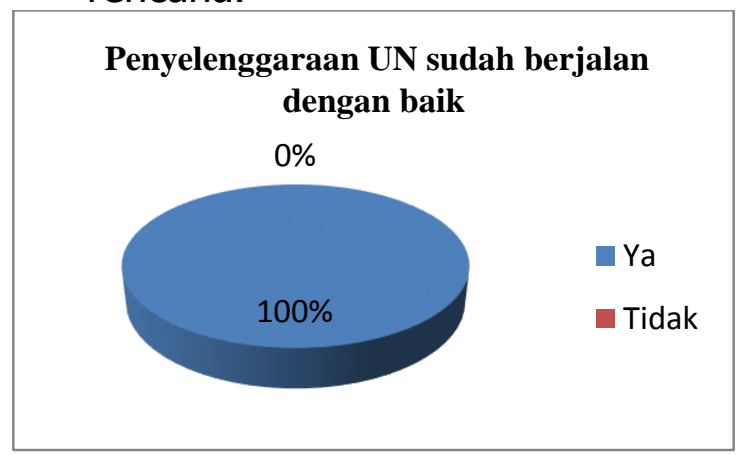

2. Namun demikian, meskipun pada poin sebelumnya pelaksanaan Ujian Nasional (UN) telah terlaksana dengan baik, namun masih ada oknum-oknum tertentu yang melakukan kecurangan pada UN tahun 2015 ini. Selain itu kebocoran soal Bahasa Indonesia pada hari pertama melalui internet, menjadi pelajaran penting bagi seluruh penyelenggara dan pelaksana UN. Berdasarkan hal-hal tersebut di atas, $90 \%$ responden menjawab penyelenggaraan UN sudah cukup baik dan sesuai dengan POS atau prosedur yang ada, dan $10 \%$ menjawab masih terlihat adanya tindak kecurangan oleh oknum tertentu.

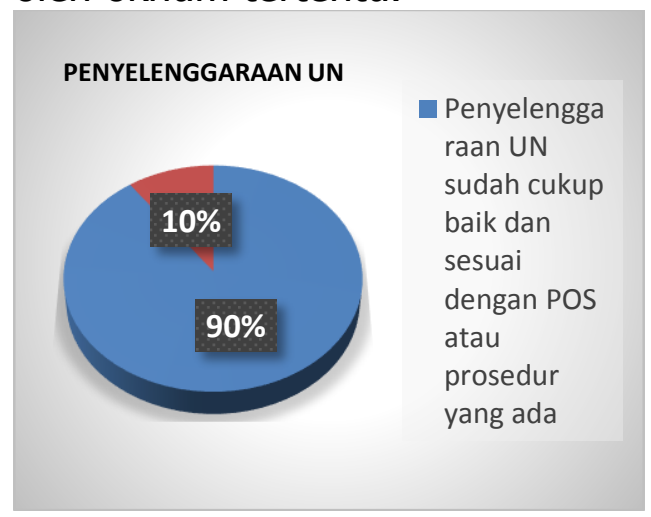

3. Begitupula dalam hal supervisi Ujian Nasional (UN), seluruh responden menjawab bahwa supervisi pada UN 2015 sudah berjalan dengan baik, hal ini terlihat dari diagram Pie berikut ini:

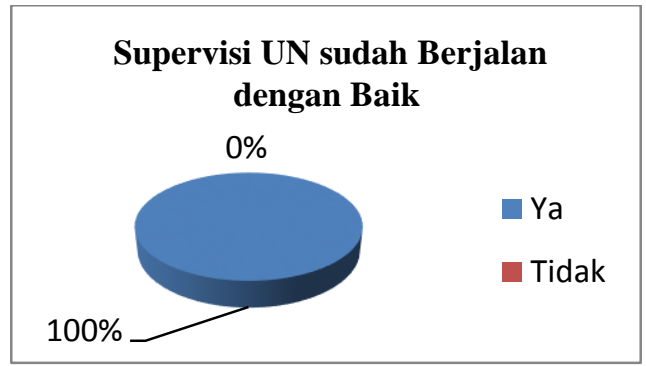

4. Berkaitan dengan Supervisi tersebut di atas, didasari atas halhal sebagai berikut:

a. Pengawas dan pejabat dari suku dinas, dinas pendidikan dan beberapa pejabat terkait memantau ke sekolah pada saat pelaksanaan UN berlangsung

b. Tim memantau dan tidak ada indikasi kesalahan fatal, supervisi dilakukan dengan SK dari Suku Dinas sampai 
dengan Menteri Pendidikan dan Kebudayaan.

c. Pelaksanaan supervisi dilakukan baik secara langsung maupun tidak langsung setiap hari pada saat pelaksanaan UN berlangsung, pelaksanaan UN secara tidak langsung dilaksanakan melalui jejaring sosial media.

Supervisi Ujian Nasional (UN)

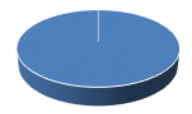

- Supervisi UN sudah berjalan dengan baik, team sudah memantau serta adanya pengawas di tiap pelaksanaan UN berlangsung

5. Mengenai Kendala-kendala yang dihadapi pada Ujian Nasional (UN) 2015, berdasarkan hasil wawancara didapat hasil $80 \%$ responden menjawab tidak ada kendala dan $20 \%$ responden menjawab ya (terdapat kendala) .

Kendala yang dihadapi

$20 \%$

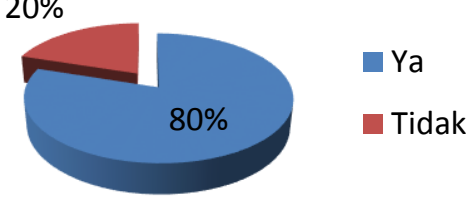

6. Kendala-kendala yang dihadapi pada Ujian Nasional (UN) 2015, berdasarkan dari hasil wawancara didapat bahwa $10 \%$ responden menyatakan tidak ada kendala dalam pelaksnaan UN, $60 \%$ responden menyatakan terdapat sedikit kendala pada pelaksanaan UN, 10\% kendala terdapat pada operasional sistem yang belum memadai atau belum sempurna, dan $20 \%$ responden tidak menjawab.

Kendala-kendala yang dihadapi UN

$20 \% 10 \%$

$10 \%$

$60 \%$

Kendala-kendala yang terjadi memang bukan permasalahan yang besar, misalnya adalah permasalahan pada saat persiapan, beberapa soal yang membutuhkan waktu lama pada saat di download, operasiona yang belum sempurna dari pusat. Namun hal-hal tersebut masih dapat ditangani dengan baik.

7. Mengenai antisipasi permasalahan tersebut, dapat dilihat dari jawaban hasil wawancara seluruh responden yang menjawab $\mathrm{Ya}$, bahwa pemerintah dapat mengantisipasi masalah tersebut.

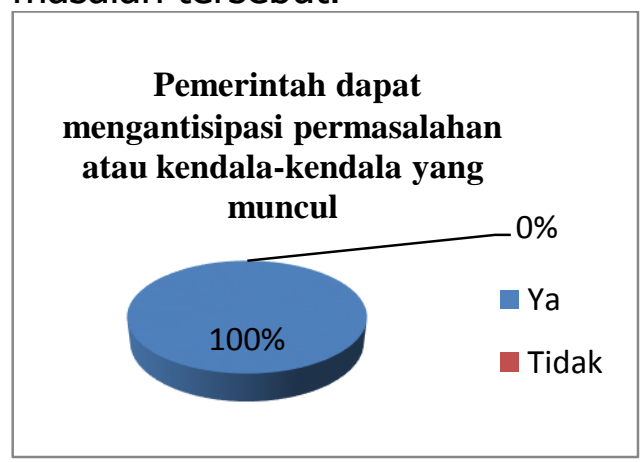

8. Pemerintah dapat mengantisipasi masalah-masalah yang terjadi, dengan memberikan Juknis dan sosialisasi kepada operator sekolah dan kepala sekolah, serta solusi yang tepat dengan selalu bekerja sama dengan seluruh 
pihak terkait pelaksanaan Ujian Nasional (UN) 2015. Keterlambatan soal yang selalu terjadi, diantisipasi dengan pendistribusian soal yang dilakukan pada malam hari, dan segala permasalahanpermasalahan yang ada ditangani dengan cepat, serta selalu berkoordinasi dengan Rayon, maupun Korwil.

\section{Indikator Keberhasilan Tahap Proses Program Ujian Nasional (UN)}

Indikator keberhasilan pada tahap proses UJIAN NASIONAL (UN) ini melihat pada aspek-aspek tersebut maka disimpulkan bahwa tahap proses berhasil dengan baik, hal ini dapat terlihat dari pernyataanpernyataan yang menyatakan bahwa proses Ujian Nasional (UN) telah dilaksanakan dengan baik, tanpa kendala yang berarti, meskipun demikian, para responden memberikan masukan-masukan sebagai berikut:

a. Seperti pada tahap proses supervisi, walaupun supervisi sudah berjalan, tetapi tetap diperlukan lembaga independen dalam monitoring dan evaluasi dan tidak hanya bersifat formalitas.

b. Dalam hal penyelenggaraan Ujian Nasional masih diperlukan perbaikan-perbaikan terutama dalam hal Ujian Nasional CBT, sehingga waktu pelaksanaan dapat benar-benar berjalan sesuai dengan rencana, melalui mudahnya mendownload soalsoal, ketersediaan prosedur UN CBT yang mumpuni, dan pelaksanaan UN CBT yang menyeluruh di seluruh sekolah.

\section{Evaluasi Produk Program Ujian Nasional (UN)}

Beberapa hal yang dapat dievaluasi dari produk Program Ujian Nasional (UN)2015, yaitu:

1. Kompetensi lulusan Ujian Nasional (UN) telah tercapai. Hal tersebut dapat dilihat dari hasil seluruh responden menjawab Ya.

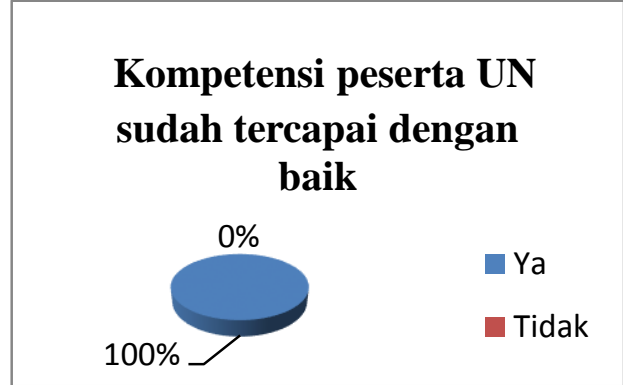

2. Berdasarkan hasil tersebut di atas, dapat dipetakan bahwa hasil kompetensi para peserta UN dapat diilihat dari jawaban hasil wawancara, yakni $20 \%$ terjadi penurunan angka nilai kompetensi peserta UN, $10 \%$ adanya peningkatan pada nilai peserta UN walaupun tidak signifikan, $70 \%$ kompetensi peserta UN tercapai dengan baik.

\section{Kompetensi Peserta UN}

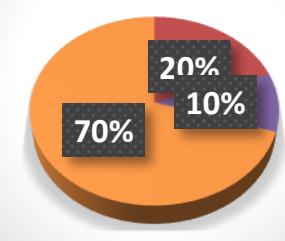

3. Berkaitan dengan ada tidaknya kriteria pemetaan kualitas Ujian Nasioan (UN), jawaban responden atas wawancara kami adalah $60 \%$ menyatakan belum 
ada kriteria pemetaan kualitas Ujian Nasional dan $40 \%$ menyatakan sudah ada kriteria pemetaa kualitas Ujian Nasional.

Terdapat kriteria Pemetaan

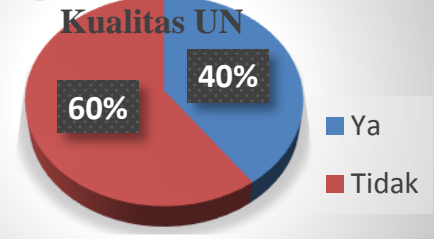

4. Kriteria pemetaan kualitas UN tidak ada, hal ini tergambar dari pernyataan bahwa pemetaan kualitas Ujian Nasional (UN) hanya menggambarkan peringkat secara umum, tidak secara spesifik, hanya terlihat peringkat sekolah dari UN maupun provinsi dan wilayah. Berdasarkan jawaban dari SMKN 41 Jakarta, Pemetaan disesuaikan dengan SKN dan terdapat kriteria minimal ketercapaian hasil Ujian Nsional (UN), di mana berdasarkan hal tersebut siswa yang di bawah kriteria tahun ini lebih banyak. Sedangkan beberapa sekolah mengatakan bahwa hasil UN selama ini dapat dilihat di media dari berbagai survey yang dilakukan.

5. Pendapat, rekomendasi serta saran untuk Program Ujian Nasional (UN) selanjutnya adalah sebagai berikut:

a. SMKN 8 Jakarta menyatakan bahwa sosialisasi UN sebaiknya dilaksanakan jauh-jauh hari dan POS dikeluarkan jauh-jauh hari sehingga isu-isu ketidak jelasan tentang Ujian Nasional (UN) dapat diminimalisir. b. Kepala SMKN 18 Jakarta menyatakan bahwa Ujian Nasional (UN) sebaiknya ditiadakan karena ada nilai sekolah yang dapat membantu kelulusan. Sedangkan Ketua Program Studi Administrasi Perkantoran menyatakan bahwa UN tetap dilaksanakan sebagai standar mutu pendidikan nasional.

c. SMKN 20 Jakarta menyatakan agar Ujian Nasional (UN) PBT agar disosialisasikan untuk Ujian Nasional (UN) CBT agar sekolah lebih dilengkapi prasarananya.

d. SMKN 25 Jakarta menyatakan bahwa jika Ujian Nasional (UN) harus dilaksanakan dengan metode CBT maka perlu diadakan pelatihan pembatan soal CBT untuk para guru.

e. Kepala SMKN 41 Jakarta menyatakan bahwa Program Ujian Nasional (UN) tetap dilanjutkan karena sebagai tolok ukur atau acuan peserta didik. Sedangkan Ketua Program Studi Adminisrasi Perkantoran menyatakan bahwa perlu lebih teliti lagi dalam pengawasan agar lebih baik sehingga tidak terdapat kecurangan.

f. Kepala SMKN 62 Jakarta menyatakan bahwa Ujian Nasional (UN) dapat menerapkan supervisi yang lebih baik lagi dari saat ini. Selanjutnya Ketua Program Studi Administrasi Perkantoran menyatakan perlu tindak lanjut khsusus kepada sekolah yang 
belum mencapai kriteria kualitas guru agar di tahun yang akan datang walaupun tetap tidak sebagai penentu kelulusan. Sebagai lembaga pendidikan tetap berorientasi mutu dalam KBM yang berujung pada pencapaian hasil Ujian Nasional (UN) peserta didik.

\section{Indikator Keberhasilan Produk} Program UjianNasional (UN)

Indikator keberhasilan pada tahap produk Ujian Nasional (UN) ini melihat pada aspek-aspek tersebut maka disimpulkan bahwa tahap proses cukup berhasil, karena:

a. Sebagian besar kualitas kompetensi peserta Ujian Nasiona (UN) tercapai dengan baik

b. Belum ada kriteria pemetaan kualitas Ujian Nasional (UN), menyebabkan belum terlihat secara jelas kriteria kualitas lulusan yang baik atau tidak baik, yang terlihat hanya peringkatnya saja.

\subsection{Pembahasan}

Dengan mempelajari hasil wawancara dengan para responden (key informan), maka dapat peneliti simpulkan bahwa ada kesesuaian antara rencana atau prosedur yang ditetapkan dalam Program UN dengan implementasinya di lapangan, sehingga kita tidak akan melihat adanya kesalahan yang besar karena sebagian besar prosedur telah ilaksanakan dengan baik.

\section{Isu Peningkatan sarana dan prasarana}

Berdasarkan hasil wawancara peneliti dengan para kepala SMK
Negeri dan Ketua Program Studi Administrasi Perkantoran di Jakarta Selatan. Kepala SMK Negeri 18 menyatakan bahwa perlu adanya penyesuaian dan kesetaraan rasio antara jumlah kelas, ruang, pengawas, siswa dan dana, sedangkan kepala SMK Negeri 20 menyataskan perlunya penambahan komputer dan IT yang memenuhi kriteria dalam menunjang Ujian Nasional.

Sependapat dengan beberapa pendapat di atas, peneliti juga menilai perlu adanya peningkatan sarana dan prasarana dalam penyelenggaraan program Ujian Nasional (UN) agar dapat menjalankan kegiatan dengan baik, didukung oleh model pembiayaan yang baik.

\subsection{Rekomendasi \\ Keberlanjutan Program UJIAN NASIONAL (UN) dengan perbaikan}

Dengan memperhatikan isu strategis dalam Program yang telah disebutkan sebelumnya, maka kami merekomendasikan beberapa hal pada kegiatan Program Ujian Nasional (UN), yaitu:

1. Kisi-kisi Ujian Nasional (UN) dapat diakses melalui internet.

2. Fungsi Ujian Nasional (UN) adalah sebagai pemetaan, seleksi jenjang yang lebih tinggi dan pembinaan, bukan sebagai penentu/syarat kelulusan.

3. Pelaksanaan Ujian Nasional (UN) Computer Based Test (CBT) dapat diterapkan oleh seluruh sekolah, bukan hanya dilaksanakan oleh sebagian sekolah saja, sedangkan 
sebagian lainnya masih melaksanakan Paper Based Test (PBT).

4. Perlu penyesuaian sarana dan prasarana yang memadai seiring berjalannya program Ujian Nasional (UN) yang baru dan bertambahnya jumlah peserta agar ada keseimbangan antara input dan output yang diharapkan.

5. Pengendalian informasi dan teknologi (IT), sehingga dapat meminimalisir terjadinya kebocoran melalui internet, baik itu melalui jejaring sosial maupun sosial media lainnya.

6. Perlu pengawasan yang lebih obyektif dan bukan hanya formalitas semata, sehingga kecurangan-kecurangan dapat diatasi dengan baik.

\section{KESIMPULAN DAN SARAN}

\subsection{Kesimpulan}

1. Dalam konteks perencanaan dan penyelenggaraan program Ujian Nasional sudah baik, karena Program Ujian Nasional memiliki dasar hukum yang jelas

2. Indikator Keberhasilan Tahap Input Program Ujian Nasional sudah baik.

3. Indikator keberhasilan pada tahap proses Ujian Nasional berhasil dengan baik, hal ini dapat terlihat dari pernyataan-pernyataan bahwa proses Ujian Nasional telah dilaksanakan dengan baik, tanpa kendala yang berarti.
4. Pada produk program Ujian Nasional jika ditinjau dari pelaksanaannya belum terlihat jelas kriteria kualitas lulusan yang baik atau tidak baik, yang terlihat hanya peringkatnya saja.

\subsection{Saran}

1. Fungsi Ujian Nasional (UN) adalah sebagai pemetaan, seleksi jenjang yang lebih tinggi dan pembinaan, bukan sebagai penentu/syarat kelulusan.

2. Masih perlu peningkatan pada sarana dan prasarana UN PBT maupun UN CBT yang memadai sesuai rasio antara peralatan dengan peserta UN.

3. Perlu tersedianya pengawas silang pada UN CBT.

4. Perlu pengawasan yang lebih obyektif .

5. Pelaksanaan Ujian Nasional (UN) Computer Based Test (CBT) dapat diterapkan oleh seluruh sekolah.

6. Perlu penyesuaian sarana dan prasarana yang memadai

7. Pengendalian informasi dan teknologi (IT).

\section{DAFTAR PUSTAKA}

Arikunto, S. (2012). Dasar-dasar Evaluasi Pendidikan. Jakarta: Bumi Aksara.

Arikunto, S. d. (2007). Evaluasi Program Pendidikan. Jakarta: Bumi Aksara.

Easton, D. (1953). The Political System. New York: Knopf. 
Howlett, M. a. (1995). Kebijakan Publik, Formulasi, Implementasi dan. Evaluasi Pendidikan. Jakarta: PT Gramedia.

Wawan. (2011). Evaluasi Teori, Model, Standar, Aplikasi, dan Profesi. Jakarta: PT.

Rajagrafindo Persada. 